\title{
CrimRxiv
}

\section{Drugs Politics: Managing Disorder in the Islamic Republic of Iran}

\section{Maziyar Ghiabi}

Published on: Jun 19, 2019

DOI: 10.21428/cb6ab371.aeaf3a99

License: Creative Commons Attribution 4.0 International License (CC-BY 4.0). 
